\title{
SOSIALISASI PAJAK BUMI DAN BANGUNAN PEDESAAN DAN PERKOTAAN.
}

\author{
Wayan Resmini'1), Abdul Sakban'1), Ni Putu Ade Resmayani²) \\ 1)Program Studi PPKn, FKIP, Universitas Muhammadiyah Mataram, Mataram, NTB, Indonesia \\ 2)Program Studi Pariwisata Sekolah Tinggi Pariwisata Mataram, Mataram, NTB, Indonesia \\ Corresponding author: Ni Putu Ade Resmayani \\ E-mail: aderesmayani@gmail.com
}

Diterima 18 Maret 2021, Direvisi 20 April 2021, Disetujui 20 April 2021

\begin{abstract}
ABSTRAK
Pajak adalah peralihan kekayaan dari pihak rakyat kepada kas negara untuk membiayai pengeluaran rutin dan surplusnya digunakan untuk public saving yang merupakan sumber pendapatan negara. Sedangkan pajak daerah adalah pajak negara yang diserahkan kepada daerah untuk dipungut berdasarkan peraturan perundang-undangan yang dipergunakan untuk pembiayaan daerah sebagai badan hukum public. Tindak lanjutnya, ditetapkan Peraturan Daerah Kota Mataram Nomor 15 Tahun 2018 tentang Pajak Bumi dan Bangunan Perdesaan dan Perkotaan (PBB-P2). Peraturan Daerah ini diharapkan menjadi landasan hukum dalam pengenaan Pajak daerah.. Untuk itu perlu adanya sosialisasi tentang betapa pentingnya masyarakat memiliki kesadaran dalam melakukan kewajiban untuk membayar pajak bumi dan bangunan. Karena dalam kenyataannya masyarakat masih banyak yang belum menyadari hal tersebut. Sosialisasi ini mengambil lokasi di Kecamatan Mataram Timur, Kota Mataram, Nusa Tenggara Barat. Lokasi ini berada di dalam kota Mataram. Adapun tujuan pengabdian pada masyarakat ini, adalah sebagai berikut: Untuk memberikan pemahaman dan pendidikan tentang : tata cara pembayaran pajak bumi dan bangunan, cara mengajukan keberatan penetapan pajak bumi dan bangunan, cara pengembalian kelebihan pembayaran pajak bumi dan bangunan oleh wajib pajak. Metode kegiatan ini dilaksanakan dengan metode ceramah, diskusi dan Tanya jawab. Tata cara Pembayaran dan Penagihan Pajak adalah sebagai berikut: Pajak yang terhutang berdasarkan SPPT harus dilunasi selambat-lambatnya 5 (lima) bulan sejak tanggal diterimanya SPPT oleh wajib pajak, Pada saat jatuh tempo pembayarannya tidak dibayar atau kurang dibayar, dikenakan sanksi administrasi berupa bunga sebesar $2 \%$ setiap untuk jangka waktu paling lama 15 bulan sejak saat terhutangnya pajak. Tata cara mengajukan keberatan pajak yang ditentukan oleh walikota. Wajib pajak dapat mengajukan keberatan kepada Walikota atau pejabat yang ditunjuk atas sesuatu tentang: SPPT; SKPD;SKPDLB); dan SKPDN. Keberatan harus dilakukan dalam jangka waktu paling lama 3 (tiga) bulan sejak tanggal surat. Cara pengembalian Kelebihan pembayaran Pajak Bumi dan Bangunan Atas kelebihan pembayaran pajak, Wajib pajak dapat mengajukan permohonan pengembalian kepada Walikota. Kesadaran masyarakat dalam pembayaran pajak perlu ditingkatkan, hal ini harus diperhatikan dan dimaksimalkan oleh pemerintah daerah Kota Mataram dan instansi terkait, karena masih banyak masyarakat belum menyadari alangkah pentingnya peran dan fungsi pajak badi pembangunan daerah. Hasil pengamatan dan Tanya jawab pada saat pelaksanaan Pengabdian masyarakat Faktor kesadaran masyarakat yang masih rendah, informasi tentang batas akhir pembayaran pajak kurang jelas dari instansi yang terkait. Kesulitan lainnya adalah tempat pembayaran pajak juga menjadi kendala Karen jarak tempuh kurang lebih 3-4 km dari tempat tinggal. Biasanya masyarakat baru membayar pajak saat terjadinya jual beli terhadap obyek pajak.
\end{abstract}

Kata Kunci: pajak; bumi, bangunan; perkotaan; pedesaan.

\begin{abstract}
Taxes are the transfer of wealth from the people to the state treasury to finance routine expenses, and the surplus is used for public saving, which is a source of state income. Meanwhile, regional taxes are state taxes submitted to the regions to be collected based on statutory regulations used for regional financing as public legal entities. As a follow-up, the Mataram City Regional Regulation Number 15 of 2018 concerning Rural and Urban Land and Building Tax (PBB-P2) has been stipulated. This Regional Regulation is expected to become a legal basis in the imposition of regional taxes. For this reason, there is a need for socialization about how important it is for people to have awareness in carrying out their obligations to pay land and building taxes. Because in reality, there are still many people who are not aware of this. This socialization took place in the East Mataram District, Mataram City, West Nusa Tenggara. This location is in the city of Mataram. This community service's objectives are as follows: To provide understanding and education regarding procedures for paying land and building taxes, how to file objections to the determination of land and building tax, how to return overpayments of land, and to
\end{abstract}


build tax by taxpayers. This activity's method is carried out using lecturing, discussion, and question and answer sessions. Procedures for Payment and Collection of Taxes are as follows: Tax payable based on the SPPT must be paid not later than 5 (five) months from the date of receipt of the SPPT by the taxpayer. At the due date, the payment is not paid or underpaid, shall be subject to administrative sanctions in the form of interest in the amount of $2 \%$ for a period of no later than 15 months from the time the tax became due. The Mayor determines the procedure for filing a tax objection. The taxpayer can file an objection to the Mayor or the appointed official regarding SPPT, SKPD, SKPDLB), and SKPDN. Objections must be made within a maximum period of 3 (three) months from the letter's date. To return the overpayment of Land and Building Tax Excess Payment upon tax overpayment, taxpayers can apply for a refund to the Mayor. Public awareness in paying taxes needs to be improved. This must be considered and maximized by the regional government of Mataram City and related agencies, because there are still many people who do not realize the importance of the role and function of taxes for regional development. The results of observations and discussions during the implementation of community service, this problem is caused by public awareness factors that are still low and lack of information about the deadline for tax payments from the relevant agencies. Another difficulty is where to pay taxes which is a constraint because the distance is approximately $3-4 \mathrm{~km}$ from the place of residence. Usually, people only pay taxes when the tax object is bought and sold.

Keywords: tax; land; building; urban area; rural area

\section{PENDAHULUAN}

Pajak adalah iuran wajib kepada negara (yang dapat dipaksakan), wajib pajak harus membayarnya menurut peraturan yang berlaku dan tidak mendapat prestasi-kembali secara langsung, gunanya adalah untuk membiayai pengeluaran-pengeluaran umum yang berhubungan dengan tugas negara. Pungutan yang dilakukan oleh pemerintah berdasarkan Undang-Undang tanpa adanya jasa timbal balik atau prestasi yang dapat dirasakan oleh si pembayar pajak dan hasilnya dimasukan ke dalam khas negara selanjutnya akan digunakan untuk membiayai pengeluaran umum pemerintah melalui APBN.

Menurut Rochmat Soemitro (2015:79) pajak adalah iuran rakyat kepada Kas Negara berdasarkan Undang-Undang (yang dapat dipaksakan) dengan tiada mendapat jasa timbal (kontra prestasi) yang langsung dapat ditunjukkan dan yang digunakan untuk membayar pengeluaran umum. Definisi tersebut kemudian dikoreksinya yang berbunyi sebagai berikut, Pajak adalah peralihan kekayaan dari pihak rakyat kepada Kas Negara untuk membiayai pengeluaran rutin dan surplusnya digunakan untuk public saving yang merupakan sumber pendapatan daerah.Demikian dicantumkan dalam UndangUndang Nomor. 34 Tahun 2000 tentang Pajak Daerah.

Pengertian Pajak Daerah sebagaimana diatur dalam Undang-Undang Nomor 34 Tahun 2000 tentang Perubahan Undang-Undang Nomor.18 Tahun 1997 tentang Pajak Daerah Dan Retribusi Daerah, dinyatakan bahwa "Pajak Daerah, yang selanjutnya disebut pajak, adalah iuran wajib yang dilakukan oleh orang pribadi atau badan kepada Daerah tanpa imbalan yang seimbang, yang dapat dilaksanakan berdasarkan peraturan perundang-undangan yang berlaku, yang digunakan untuk membiayai penyelenggaran pemerintahan Daerah dan pembangunan Daerah.

Dengan demikian dapat dikatakan bahwa pajak daerah adalah pajak negara yang diserahkan kepada daerah untuk dipungut berdasarkan peraturan perundang-undangan yang dipergunakan untuk pembiayaan daerah sebagai badan hukum publik. Ada beberapa hal yang menjadi ciri-ciri pajak daerah antara lain:

1. Pajak daerah berasal dari pajak negara yang diserahkan kepada daerah sebagai pajak daerah

2. Pajak daerah dipunggut oleh daerah berdasarkan kekuatan undangundang dan aturan peraturan hukum lainnya.

3. Hasil pungutan pajak dengan dipergunakan untuk membiayai penyelenggaraan urusan-urusan rumah tangga daerah atau untuk membiayai pengeluaran daerah sebagai badan hukum publik.(Brotodihardjo. Santoso. 2016 :43)

Undang-Undang Nomor 34 Tahun 2000 menyebutkan bahwa pajak daerah harus memenuhi pengertian tentang pajak itu sendiri secara obyektif, sehingga pengenaan pajak sesuai dengan undang-undang tetap mengacu pada kepentingan dan kemampuan masyarakat itu sendiri.

Pengelolaan pajak daerah diatur oleh pemerintah daerah dengan menempuh kebijaksanaan asas kebebasan yaitu kebebasan daerah untuk menentukan 
besarnya tarif pajak tertentu, seperti pajak reklame, pajak pembangunan dll. Kebebasan ini dimungkinkan karena pemerintah pusat tidak mencapuri terlalu jauh pengelolaan pajak daerah, disamping itu kontrol pemerintah pusat dalam melaksanakan kebijaksanaan dalam bidang pajak daerah sesuai dengan kebutuhan dan keinginan daerah.( Djuhadiyat. S Jajat. 2016 : 23)

Pajak Daerah merupakan kontribusi wajib pajak bagi daerah yang terutang oleh orang pribadi atau badan yang bersifat memaksa berdasarkan Undang-undang dengan tidak mendapatkan imbalan secara langsung dan digunakan untuk keperluan daerah bagi sebesar-besarnya kemakmuran rakyat. Selain itu pula, Pajak Daerah merupakan salah satu sumber pendapatan Asli Daerah yang memiliki peranan yang sangat strategis dalam meningkatkan kemampuan keuangan daerah dalam membiayai penyelenggaraan Pemerintahan Daerah dan pelayanan umum.(Kansil.C.S.T. $2015: 21$ )

Pasal 2 ayat (1) huruf $j$ Undang Undang Nomor 28 Tahun 2009 tentang Pajak Daerah dan Restribusi Daerah, disebutkan bahwa Pajak bumi dan Bangunan Perdesaan dan Perkotaan merupakan jenis pajak Kabupaten/kota, sehingga Pemerintah Kota Mataram berwenang memungut Pajak Bumi dan Bangunan khususnya sektor Perkotaan dalam Peraturan Daerah.

Tindak lanjut dari ketentuan tersebut di atas, ditetapkan Peraturan Daerah Kota Mataram Nomor 15 Tahun 2018 merupakan perubahan terhadap Peraturan Daerah No 7 Tahun 2012 tentang Pajak Bumi dan Bangunan Perdesaan dan Perkotaan ( (PBB-P2). Peraturan Daerah ini diharapkan menjadi landasan hukum dalam pengenaan Pajak Daerah sehubungan dengan hak atas bumi dan/ atau kepemilikan, penguasaan, pembiayaan pembangunan sesuai dengan kemampuan dan/ atau perolehan manfaat atas bangunan. Selain itu dengan berlakunya Peraturan Daerah ini diharapkan dapat memberikan kesadaran, kepastian hukum dan keadilan bagi masyarakat untuk berpartisipasi dalam pembiayaan pembangunan sesuai dengan kemampuan daerah. Peraturan Daerah ini sebagai landasan hukum dalam pemungutan pajak bumi dan bangunan yang berada di wilayah Kota Mataram. Untuk itu perlu adanya sosialisasi tentang betapa pentingnya masyarakat memiliki kesadaran dalam melakukan kewajiban untuk membayar pajak bumi dan bangunan. Karena dalam kenyataannya masyarakat masih banyak yang belum menyadari hal tersebut.

\section{METODE}

Pelaksanaan sosialisasi hukum pada pengabdian masyarakat ini mengambil lokasi di Kecamatan Mataram Timur, Kota Mataram, Nusa Tenggara Barat.Lokasi ini berada di dalam kota Mataram.Sosialisasi hokum ini dilaksanakan dengan melibatkan Tim Pengabdian Masyarakat Program Studi PPkn FKIP Universitas Muhammadiyah Mataram bekerja sama dengan Tim Pengabdian Masyarakat Sekolah Tinggi Pariwisata Mataram dan Kantor Kecamatan Mataram Timur. Sosialisasi ini dilaksanakan secara langsung dengan tetap memperhatikan peraturan dan tata tertib Covid 19 yaitu menerapkan 3M (mempergunakan masker, mengatur jarak, dan mencuci tangan). Jumlah subyek yang hadir sebanyak 18 orang yang terdiri dari pegawai Kecamatan, Kepala kelurahan, kepala lingkungan dan perwakilan masyarakat setempat. Mereka diharapkan dapat menbantu mensosialisasikan perda tersebut melalui kegiatan yang dilaksanakan oleh masyarakat. Metode kegiatan ini dilaksanakan dengan metode ceramah, diskusi dan Tanya jawab. Metode ceramah dipergunakan untuk pemaparan materi, selanjutnya dipergunakan diskusi dan Tanya jawab.

\section{HASIL DAN PEMBAHASAN \\ Tata Cara Pembayaran Dan Penagihan Pajak Bumi Dan Bangunan Pedesaan Dan Perkotaan.}

1. Pajak yang terhutang berdasarkan Surat Pemberitahuan Pajak Terhutang (SPPT) harus dilunasi selambat-lambatnya 5 (lima) bulan sejak tanggal diterimanya SPPT oleh wajib pajak.

2. Surat Pemberitahuan Pajak Tagihan (SPPT),Surat Ketetapan Pajak Daerah (SKPD), Surat Tagihan Pajak Daerah (STPD), Surat Keputusan Pembetulan , Surat Keputusan Keberatan, dan Putusan Banding, yang menyebabkan jumlah pajak yang harus dibayar bertambah merupakan dasar penagihan pajak yang harus dibayar bertambah merupakan dasar penagihan pajak dan harus dilunasi dalam jangka waktu paling lama 1 (satu) bulan sejak tanggal diterbitkan.

3. Pada saat jatuh tempo pembayarannya tidak dibayar atau kurang dibayar, dikenakan sanksi administrasi berupa bunga sebesar $2 \%$ (dua persen) setiap untuk jangka 
waktu paling lama 15 (lima belas) bulan sejak saat terhutangnya pajak.

4. Wali kota atas permohonan Wajib Pajak setelah memenuhi persyaratan yang ditentukan dapat memberikan persetujuan kepada Wajib Pajak untuk membayar pajak sekaligus tanpa diangsur, dengan dikenakan bunga sebesar $2 \%$ (dua persen).

5. Pajak yang terhutang dibayar ke Kas Umum Daerah atau tempat yang pembayaran yang ditunjuk oleh Walikota.

$5 a$ Seluruh ketetapan yang tidak dibayarkan wajib pajak setelah jatuh tempo dapat dilakukan pemberitahuan.

6. Ketentuan lebih lanjut mengenai tata cara pemberitahuan, pembayaran, penyetoran dan tempat pembayaran pajak diatur dengan Peraturan Wali Kota.

\section{Tata Cara Mengajukan Keberatan Pajak Yang Ditentukan Oleh Walikota}

1. Wajib pajak dapat mengajukan keberatan kepada Walikota atau pejabat yang ditunjuk atas sesuatu tentang: SPPT; SKPD; Surat Ketetapan Pajak Daerah Lebih Bayar (SKPDLB); dan Surat Ketetapan Pajak Daerah Nihil (SKPDN).

2. Keberatan diajukan secara tertulis dalam bahasa Indonesia dengan disertai alas an-alasan yang jelas.

3. Keberatan harus dilakukan dalam jangka waktu paling lama 3 (tiga) bulan sejak tanggal surat, tanggal pemotongan atau pemungutan , kecuali jika Wajib Pajak dapat menunjukkan bahwa jangka waktu itu tidak dapat dipenuhi karena keadaan di luar kekuasaannya.

4. Keberatan dapat diajukan apa paling sedikit bila Wajib Pajak telah membayar paling sedikit sejumlah yang telah disetujui Wajib Pajak.

5. Keberatan yang tidak sesuai dengan aturan yang berlaku tidak dianggap sebagai Surat Keberatan sehingga tidak dipertimbangkan.

6. Tanda penerimaan Surat Keberatan yang diberikan oleh Walikota atau Pejabat yang ditunjuk atau tanda pengiriman Surat Keberatan melalui surat pos tercatat sebagai tanda bukti penerimaan surat keberatan.

7. Walikota dalam jangka waktu paling lama 12 (dua belas) bulan, sejak tanggal Surat Keberatan diterima, harus member keputusan atas keberatan yang diajukan.

8. Keputusan Walikota atas keberatan dapat berupa menerima seluruhnya atau sebagian, menolak, atau menambah besarnya pajak yang terhutang.

9. Apabila dalam jangka waktu yang telah ditentukan telah lewat dan Walikota tidak memberikan keputusan, keberatan yang diajukan tersebut dianggap dikabulkan.

10. Ketentuan lebih lanjut mengenai tata cara pengajuan dan penyelesaian keberatan diatur dengan keputusan Walikota.

\section{Cara Pengembalian Kelebihan Pembayaran Pajak Bumi Dan Bangunan.}

1. Atas kelebihan pembayaran pajak, Wajib pajak dapat mengajukan permohonan pengembalian kepada Walikota.

2. Walikota dalam jangka waktu paling lama 12 (dua belas) bulan, sejak diterimanya permohonan pengembalian kelebihan pembayaran pajak harus memberikan keputusan.

3. Apabila dalam jangka waktu yang telah ditentukan telah dilampaui dan Walikota tidak dapat memberikan suatu keputusan, permohonan pengembalian pembayaran pajak dianggap dikabulkan dan Surat Ketetapan Pajak Daerah Lebih Bayar (SKPDLB) harus diterbitkan dalam jangka waktu paling lama 1 (satu) bulan.

4. Apabila wajib pajak mempunyai hutang pajak lainnya, kelibihan pembayaran pajak sebagaimana telah ditetapkan langsung diperhitungkan untuk melunasi terlebih dahulu utang pajak tersebut.

5. Pengembalian kelebihan pembayaran kelebihan pembayaran pajah dilakukan dalam jangka waktu paling lama 2 (dua) bulan sejak diterbitkan SKPDLB.

6. Jangka pengembalian kelebihan pembayaran pajak dilakukan setelah lewat 2 (dua) bulan, Walikota memberikan imbalan bunga $2 \%$ (dua persen) setiap bulan atas keterlambatan kelebihan pembayaran pajak.

7. Ketentuan lebih lanjut mengenai tata cara pengembalian kelebihan pembayaranpajak diatur dengan peraturan walikota. 
Kesadaran masyarakat dalam pembayaran pajak perlu ditingkatkan, hal ini harus diperhatikan dan dimaksimalkan oleh pemerintah daerah Kota Mataram dan instansi terkait, karena masih banyak masyarakat yang belum menyadari alangkah pentingnya peran dan fungsi pajak bagi pembangunan daerah. Hasil pengamatan dan tanya jawab pada saat pelaksanaan Pengabdian masyarakat bahwa Faktor kesadaran masyarakat yang masih rendah, informasi tentang batas akhir pembayaran pajak kurang jelas dari instansi yang terkait. Kesulitan lainnya adalah tempat pembayaran pajak juga menjadi kendala karena jarak tempuh kurang lebih 3-4 km dari tempat tinggal. Biasanya masyarakat baru membayar pajak saat terjadinya jual beli terhadap obyek pajak.

\section{SIMPULAN DAN SARAN Simpulan}

Tata cara Pembayaran dan Penagihan Pajak Bumi dan Bangunan Perdesaan dan Perkotaan adalah sebagai berikut: Pajak yang terhutang berdasarkan SPPT harus dilunasi selambat-lambatnya 5 (lima) bulan sejak tanggal diterimanya SPPT oleh wajib pajak.SPPT,SKPD,STPD, Surat Keputusan Pembetulan, Surat Keputusan Keberatan, dan Putusan Banding, merupakan dasar penagihan pajak dan harus dilunasi dalam jangka waktu paling lama 1 (satu) bulan sejak tanggal diterbitkan.Pada saat jatuh tempo pembayarannya tidak dibayar atau kurang dibayar, dikenakan sanksi administrasi berupa bunga sebesar $2 \%$ (dua persen) setiap untuk jangka waktu paling lama 15 (lima belas) bulan sejak saat terhutangnya pajak. Wali kota atas permohonan Wajib Pajak setelah memenuhi persyaratan yang ditentukan dapat memberikan persetujuan kepada Wajib Pajak untuk membayar pajak sekaligus tanpa diangsur, dengan dikenakan bunga sebesar $2 \%$ (dua persen). Pajak yang terhutang dibayar ke Kas Umum Daerah atau tempat yang pembayaran yang ditunjuk oleh Walikota. Pajak yang terhutang berdasarkan SPPT, SKPD, STPD, Surat Keputusan Pembetulan, Surat Keputusan Keberatan, dan Putusan banding yang tidak atau kurang dibayar oleh Wajib Pajak pada waktunya dapat ditagih dengan Surat Paksa.Penagihan pajak dengan Surat Paksa dilaksanakan berdasarkan Peraturan Perundang-undangan.

Tata cara mengajukan keberatan pajak yang ditentukan oleh walikota.Wajib pajak dapat mengajukan keberatan kepada Walikota atau pejabat yang ditunjuk atas sesuatu tentang: SPPT; SKPD;SKPDLB); dan SKPDN.
Keberatan harus dilakukan dalam jangka waktu paling lama 3 (tiga) bulan sejak tanggal surat. Cara pengembalian Kelebihan pembayaran Pajak Bumi dan Bangunan. Atas kelebihan pembayaran pajak, Wajib pajak dapat mengajukan permohonan pengembalian kepada Walikota.

\section{Saran}

Perlunya melibatkan swasta dalam penanganan pengelolaan penerimaan pendapatan daerah terutama terhadap jenis pendapatan pajak perdesaan dan perkotaan yang potensial dengan cara melakukan tenderisasi secara transparansi, dimana pemerintah daerah menjadi fasilitator. Perlunya pemberdayaan secara maksimal terhadap seluruh potensi daerah dengan menempatkan orang-orang yang memiliki pribadi integrasi terhadap kemajuan daerah Kota Mataram. Perlu ditingkatkan sistem yang lebih luas terhadap pengelolaan pajak pedesaan dan perkotaan , dengan melibatkan institusi masyarakat atau membentuk badan otonomi daerah dengan melibatkan unsur perguruan tinggi atau organisasi cendekiawan.

Pemerintah diharapkan untuk melibatkan pihak swasta melakukan pengkajian secara mendalam tentang sumber-sumber pendapatan asli daerah, termasuk cara pengelolaannya dengan melibatkan lambagalembaga pengkajian dan penelitian yang ada terutama yang berbasis di Perguruan Tinggi.

\section{DAFTAR RUJUKAN}

Brotodihardjo, R. Santoso, (2016), Pengantar Hukum Pajak, Cetakan Kesembilan, Jakarta-Bandung:PT Eresco.

Djuhadiat, S. Jajat, (2016), Pengantar Hukum Pajak, Modul DPT III Departemen Keuangan, Jakarta.

Kansil, C.S.T. (2015). Buku Saku Pajak, Jakarta:Bina Aksara

Soemitro, H. Rochmat, (2015), Asas-asas Hukum Perpajakan, Bandung: Bina Cipta BPHN.

Republik Indonesia, Undang-Undang Dasar 1945.

-,Undang-undang Nomor 18 Tahun 1997 tentang Pajak Daerah dan Kontribusi.

--,Undang-undang Nomor 34 Tahun 2000 tentang Pajak Daerah.

--,Undang-undang Nomor 28 Tahun 2009 tentang Pajak Daerah dan Kontribusi.

---Undang-undang Nomor 32 Tahun 2004 tentang Otonomi Daerah. -,Peraturan Pemerintah Nomor 19 Tahun 1997 tentang Pajak Daerah. 
Peraturan Daerah Kota Mataram Nomor 7 Tahun 2012 tentang Pajak Bumi dan Bangunan Perdesaan dan Perkotaan ( PBB-P2).

Peraturan Daerah Kota Mataram Nomor 15 Tahun 2018 tentang Pajak Bumi dan Bangunan Perdesaan dan Perkotaan ( PBB-P2). 